\title{
Praktykowanie pamięci (Mnemosyne. Pamięć jako źródło dzieła sztuki, pod red. Marii Cieśli-Korytowskiej i Jakuba Czernika, Wydawnictwo Avalon, Kraków 2016, ss. 535)
}

Zwrot pamięciowy to tendencja badawcza niezwykle heterogeniczna, bardzo żywotna i owocna obecnie w różnych dziedzinach humanistyki. Główne jej założenia, tendencje i ramy wyznaczają między innymi prace Pierre’a Nory ${ }^{1}$, Paula Ricoeura ${ }^{2}$, Aleidy i Jana Assmanów ${ }^{3}$, Douwe Draaismy ${ }^{4}$, a na gruncie polskim — Ewy Domańskiej, Jerzego Kałążnego ${ }^{6}$, Elżbiety Rybickiej ${ }^{7}$, Andrzeja Szpocińskiego ${ }^{8}$, Marii Delaperrière 9 . Przygotowana w krakowskim środowisku literaturoznawczym monografia wieloautorska Mnemosyne. Pamię́ jako źródto dzieła sz̧tuki, pod redakcją Marii Cieśli-Korytowskiej i Jakuba Czernika, świetnie wpisuje się w krąg zagadnień memory boom ${ }^{10}$. Samym tytułem książka zdaje się nawiązywać (aczkolwiek nie zaznaczono tego w niezwykle krótkim, wręcz zdawkowym wstępie) do dwu wcześniejszych, ważnych publikacji, którym patronuje bogini pamięci: Mnemosyne.

1 P. Nora, Międsy pamięciq a historiq: les lieux de memoire, tłum. M.Borowski, M.Sugiera, „Didaskalia” 2011, nr 105; tenże, Mémoire collective [w:] Faire de l'histoire, red. J. Le Goff, P. Nora, Paris 1974.

P. Ricoeur, Pamię́, bistoria i zapomnienie, przeł. J. Margański, Kraków 2006.

3 A. Assman, Przestrzenie pamięci. Formy i przemiany pamięci kulturowej, przeł. P. Przybyła [w:] Pamię́ źbiorowa i kulturowa. Wspótczesna perspektywa niemiecka, red. M. Saryusz-Wolska, Kraków 2009; J. Assman, Kultura pamięci, przeł. A. Kryczyńska-Pham [w:] Pamię́ żbiorowa i kulturowa. Współcz̨esna perspektywa niemiecka, red. M. Saryusz-Wolska, Kraków 2009.

4 D. Draaisma, Machina metafor. Historia pamięci, przeł. R. Pucek, Warszawa 2009.

5 E. Domańska, Historie niekonwencjonalne. Refleksja o przesz̧łości w nowej bumanistyce, Poznań 2006.

6 J. Kałążny, Kategoria pamięci z̧biorowej w badaniach literaturoznawcsych, „Kultura Współczesna” 2007, nr 3.

7 E. Rybicka, Miejsce, pamiéć, literatura (w perspektywie geopoetyki), ,Teksty Drugie” 2008, nr 1-2.

8 A. Szpociński, Miejsca pamięci (lieux de memoire), „Teksty Drugie” 2008, nr 4.

9 M. Delaperrière, Miejsca pamięci cày pamięć miejsc? Kilka refleksji na temat uobecniania przeszłości w literaturze wspótčesnej, „Ruch Literacki” 2013, nr 1.

10 M. Saryusz-Wolska, Memory Boom [w:] Modi memorandi. Leksylkon kultury pamieci, red. M. Saryusz-Wolska, R. Traba, Warszawa 2014. 
Formen und Funktionen der kulturellen Erinnerung pod redakcją Aleidy Assman i Dietricha Hartha ${ }^{11}$ oraz - a może przede wszystkim — do niezwykle istotnego i inspirującego także dla polskich badań intersemiotycznych dzieła włoskiego badacza, Mario Praza, Mnemosyne. Rzecz o powinowactwach literatury $i$ sztuk plastycznych ${ }^{12}$ (osobny szkic w krakowskim zbiorze poświęciła innemu tekstowi Praza, La casa della vita, Olga Płaszczewska ${ }^{13}$ ). Omawiany tom zbiorowy jest, chociaż redaktorzy o tym nie wspomnieli, pokłosiem interdyscyplinarnej konferencji zorganizowanej przez Katedrę Komparatystyki Literackiej UJ. Sympozjum odbyło się w Krakowie w listopadzie 2015 roku $^{14}$. Jak każda publikacja gromadząca w formie artykułów wystapienia z konferencji o szeroko zarysowanym obszarze refleksji, ma charakter dalece niejednolity — i ze względu na podejmowaną tematykę, i różny zakres badań oraz różnorodność autorskich ujęć. Trudno zatem byłoby uznać ją za rodzaj podręcznika do „pamięciologii”. Brak też w omawianym tomie, co oczywiste zważywszy jego kształt i genezę, uspójnienia terminologicznego, trudnego wśród artykułów historycznoliterackich (te dominuja liczbowo), filozoficznych, teatrologicznych, filmoznawczych, muzykologicznych i translatologicznych. Co zresztą ważniejsze, nie wszystkie spośród trzydziestu jeden pomieszczonych w zbiorze tekstów odnoszą się w tym samym stopniu, podobnie precyzyjnie, do formuły tytułowej „pamięci jako źródła dzieła sztuki”. Część autorów analizuje bowiem, dość tradycyjnie, przy wykorzystaniu narzędzi hermeneutycznych, obecność motywu pamięci w konkretnym dziele, inni ukazują związki intertekstualne dzieł literatury polskiej i obcej, opisują znaki pamięci, część zaś za punkt wyjścia czyni nawet nie pamięć, a tradycję czy historię. Mimo to wyprowadzić można z lektury tego wewnętrznie niezwykle zróżnicowanego zbioru istotne wnioski o charakterze bardziej generalnym. Po pierwsze, badacze silnie akcentują klasyczne, starożytne źródła współczesnej refleksji nad pamięcią i celnie tego dowodzą, po drugie — dość liczne artykuły poświęcone zagadnieniom z kręgu kultury romantycznej potwierdzają, że to w dobie romantyzmu doszukiwać się należy początku nowoczesnego rozumienia literatury oraz miejsca i funkcji artysty w świecie właśnie poprzez rozumienie i funkcjonalizowanie pamięci.

Analizowana monografia wieloautorska ma układ generalnie chronologiczny w tym sensie, że prezentowane są w niej różne zagadnienia, często wzajemnie odległe, w ich historycznym porządku. Ten klucz nie wydaje się co prawda w pełni funkcjonalny lekturowo, jednak trudno go nie zaaprobować, bowiem pozwolił redaktorom zapanować jakoś nad materią badawczą niezwykle zróżnicowaną, odnoszącą się do różnych dziedzin sztuki.

Niewyodrębnioną formalnie pierwszą część zbioru potraktować można mimo to jako ważne i pożyteczne wprowadzenie do całości zagadnienia. Stanowią ją wzajemnie się uzupełniające, a czasem wręcz niektóre rozpoznania powtarzające, dwa studia na temat istoty i wagi pamięci, Mnēmosynē, w mitologii, życiu społecznym i sztuce starożytnych Greków.

11 Mnemosyne. Formen und Funktionen der kulturellen Erinnerung, pod red. A. Assman i D. Hartha, Frankfurt am Mein 1991.

M. Praz, Mnemosyne. Rzecz o powinowactwach literatury i sztuk plastycznych, przeł. W. Jekiel, Warszawa 1981.

O. Płaszczewska, Sztuka i pamię́ w La casa della vita Mario Praz̧a [w:] Mnemosyne. Pamię́ jako źródło dżieła sæztuki, s. 389-404.

14 Zob.: E. Koziołkiewicz, Konferencja „Mnemosyne. Pamiéć jako žródto dzieła sžtuki”, Kraków 4-6 listopada 2015, „Ruch Literacki” 2015, z. 6. 
Krystyna Bartol (Mnemosyne w mitycznej i spotecznej przestrzeni Grecji staroṡytnej) opisuje, kim była dla Greków córka Gai i Uranosa, wskazując na jej ważną obecność w tekstach literackich, między innymi u Hezjoda, Pindara, Ksenofanesa, ale też podkreśla dostrzegany przez starożytnych związek boskiej ponadczasowej Mnēmosynē-Pamięci, nauczycielki prawdy i źródła wszechwiedzy i ludzkiej oraz czasowo ograniczonej mnēmosynēwspominania (oraz zapomnienia). Obie badaczka uznaje za równie istotne źródła dzieła sztuki, najpierw oralnej, potem też w kulturze słowa pisanego.

Kazimierz Korus (Mnemosyne w greckiej polityce i kulturze) dopełnia i rozwija te rozpoznania, próbując odpowiedzieć przede wszystkim na pytanie o najważniejsze dla starożytnych cechy Mnemosyne, personifikowanej Pamięci, decydujące o jej wadze i wskazuje na jej znaczenie jako boskiej wiedzy o przeszłości, teraźniejszości i przyszłości, opartej wedle ówczesnych wierzeń na prawdzie, z szacunkiem przekazywanej, wpierw w archaicznej tradycji oralnej, a potem pisanej, Pamięci jako dawczyni boskiego natchnienia.

Zdecydowanie innym tropem podąża w swoim eseju Andrzej Borowski (Pamię́, niepamiéć i nowożytne wyobrażenia na temat „Średniowiecza”), otwierający — jak można by zapewne odczytać intencje redaktorów - część drugą tomu, skupioną na nowożytnej kulturze: średniowiecza, renesansu i baroku. Erudycyjny tekst Borowskiego mieści się na marginesie kręgu zagadnień opisywanego sformułowaniem zawartym w tytule analizowanej książki. Smakowity to jednak margines. Pojęcia pamięci i zapominania służą badaczowi do opisania deformacji, jakiej uległy w czasie obraz i rozumienie średniowiecza, postrzeganego - między innymi, jak dowodzi, za sprawą Petrarki (choć sam poeta nie nazwał interesującego go okresu „średniowieczem”) — jako czas ciemny, okres upadku kultury. Borowski pisze w o kulturowym zapominaniu, proponując wprowadzenie nowego, operatywnego i ważnego jego zdaniem pojęcia „niepamięci kulturowej”. Badacz uważa je za istotne dopełnienie koncepcji „pamięci kulturowej” Aleidy Assman, uznaje za jeden z wyznaczników „humanizmu”, czyli — jak to określa — „paradygmatu człowieczeństwa kulturowego, pojmowanego jako rezultat zintegrowanego procesu wychowywania” (s. 51). To koncepcja tyleż kusząca, co dyskusyjna, jeśli zapytać o narzędzia badania owej „niepamięci kulturowej" - zwłaszcza w kontekście naturalnego społecznie procesu nie tylko zapominania, co ciagłego reinterpretowania przeszłości.

Również kolejny artykuł nie podejmuje rozważań nad istotą Mnemosyne-pamięci (jak rozumieli ją Grecy) jako źródła dzieła sztuki. Traktuje o sposobach upamiętniania zmarłych. Bogaty materiałowo tekst Jana K. Ostrowskiego ( $O d$ pars pro toto do naturalistycznego odwrorowania. Nietypowe metody upamiętniania zmartych w średniowiecznej $i$ nowożytnej Europie) to studium z zakresu historii sztuki poświęcone zapomnianym już obecnie obyczajom komemoratywnym innym niż nagrobek i utwór literacki. Autor opisuje praktyki eksponowania nad grobem zmarłego rycerza elementów jego uzbrojenia i tarczy (w Anglii, Austrii, Szwecji, Prusach Wschodnich), tablic i kartuszy herbowych (w krajach niemieckich, Szwajcarii, Wielkiej Brytanii, Holandii i Szwecji), choragwi nagrobnych (w Rzeczpospolitej i krajach ościennych), portretów trumiennych (w Rzeczpospolitej) i nagrobnych (w Rosji) oraz kap nagrobnych (w Rosji i Mołdawii), wizerunków zmarłych na łożach, katafalkach i sarkofagach (na Węgrzech, w Niemczech, Czechach, Polsce, Anglii i Holandii) oraz naturalistycznych figur zmarłych (w Anglii, Francji, Toskanii, Wenecji, Prusach). Dla niehistoryka sztuki ciekawa byłaby próba opisu, jak i dlaczego pewne obyczaje komemoratywne rozprzestrzeniały się w Europie, inne miały charakter konsekwentnie lokalny. 
Umiejscowienie jako następnego w obrębie tomu artykułu Wojciecha Ryczka (Bliźniacza siostra literatury. O metaforze tekstu pamięi) jest nieco zaskakujące, ponieważ autor analizuje ważny i wielokrotnie przez humanistów komentowany dialog antyczny Cycerona zatytułowany Partiones oratoriae (Podziały sz̨tuki wymowy), by opisać związki literatury i pamięci w ujęciu tradycyjnej retoryki. Co prawda badany przezeń tekst Cycerona ukazał się drukiem po raz pierwszy, o czym zaświadcza autor, w 1472 roku w Mediolanie, a nieco ponad czterdzieści lat później w Krakowie, niemniej należy do świata starożytnego. Refleksje Ryczka świetnie też dopełniają studia Krystyny Bartol i Kazimierza Korusa. Badacz skupia się na kluczowej, jego zdaniem, metaforze pamięci jako zapisanej karty czy woskowej tabliczki. Zestawienie mnemoniki z literatura (,zapisaną mową”) pozwala mu ukazać zasadę funkcjonowania obowiązującej na gruncie retoryki pamięci sztucznej; przypominanie to proces bliski lekturze i interpretacji. Jak pisze Ryczek, „[n]a gruncie teorii retorycznej można uznać literaturę za alegorię pamięci (...), a pamięć za alegorię literatury” (s. 101).

Być może kolejny tekst, Dorothy Figueiry (Uporzqdkować wlasne życie $i$ życie innych: Matteo Ricci i tradycja technik mnemonicznych) był powodem, dla którego poprzedził go artykuł Wojciecha Ryczka, bo też prowadzone przez amerykańską badaczkę rozważania nad typowym dla literatury klasycznej systemem mnemonicznym, z powołaniem się na autorytet $\mathrm{Cy}$ cerona, wprost korespondują z uwagami krakowskiego filologa, dotyczącymi tradycyjnej mnemoniki. Figueira sprawnie i zajmująco opisuje przypadek włoskiego jezuity, Matteo Ricciego, który u schyłku XVI wieku podjął próby przekazania Chińczykom klasycznych retorycznych technik pamięciowych, ucząc ich, jak budować „pałace pamięci”, nie o sztukę jednak Ricciemu chodziło, lecz o propagowanie idei chrześcijaństwa.

Tę niewyodrębnioną formalnie część drugą monografii wieloautorskiej dopełniają dwa artykuły. Miłowita Kunińskiego (Pamięć własna i cudza jako źródto tożsamości podmiotu moralnego), który proponuje czytelnikowi krytyczną lekcję nowożytnych koncepcji tożsamości w perspektywie pamięci, punktem wyjścia czyniąc dogłębną analizę poglądów Johna Locke’a, dla którego tożsamość osoby była związana — jak dowodzi Kuniński — ze świadomością swego ,ja”, z pamięcią samego siebie, pamięcią przeżyć i doznań (s.114), a jednocześnie, nie kwestionując roli, jaką pełni pamięć w budowaniu tożsamości osoby i samoświadomości, uwzględniał on też perspektywę zewnętrzną (s. 121). Autor omawia dyskusje wokół tej koncepcji, jakie toczyli współcześni Locke’owi i późniejsi filozofowie (Joseph Butler, Derek Parfit, Thomas Reid, Charles Taylor) — i wskazuje kontynuację tej charakterystycznej dla filozofii nowożytnej perspektywy pierwszoosobowej u Edmunda Husserla, a następnie omawia koncepcję Bildung Wilhelma von Humboldta, sądy Johna Stuarta Milla, Martina Heideggera i Jeana-Paula Sartre'a oraz tekstowy charakter autobiografii — ,retrospektywnej opowieści proza, gdzie rzeczywista osoba przedstawia swoje życie, akcentując swoje jednostkowe losy, a zwłaszcza dzieje swej osobowości” (s. 134) Philippe’a Lejeune’a.

Elżbieta Nowicka (Pamiéć teatru - pamiéć w teatræe) omawia żywy dla praktyków i teoretyków teatru na przełomie XVIII i XIX wieku dylemat „ars” i „przeżycia”, skupiając się na poglądach Antoine'a François Riccoboniego (syna) dotyczących wrażenia prawdy, jakie odnieść ma odbiorca sztuki aktorskiej, Denisa Diderota, dla którego istotnym elementem w budowie jest pamięć jako podstawa wyobraźni, dopełniająca jej i konkretyzująca ja, oraz Johanna Wolfganga Goethego, dla którego z kolei ważna była pamięć ciała, mimiki i gestów, z których aktorzy budują role. To w istocie studium różnych historycznie się kształtujących rodzajów ekspresji scenicznej. 
Największy korpus tekstów omawianego tomu zbiorowego stanowią artykuły poświęcone literaturze i kulturze doby romantyzmu, polskiej i obcej.

Tę nieformalną trzecią część tomu otwiera studium Marka Stanisza (,,Serce boli, lecz opowiadac trzeba". Strategie upamiętniania w pržedmowach do poematów romantycznych). Badacz skupia się w nim na reprezentatywnej dla poezji romantycznej formie poematu, analizując autorskie przedmowy do wybranych poematów polskich, angielskich, niemieckich, rosyjskich i ukraińskich, zarówno - jak nazywa je — „historycznych”, jak i „(pseudo)autobiograficznych”, odkrywając prawidłowość, jaką jest, jego zdaniem, lekceważenie źródeł historycznych i relacji z wydarzeń na korzyść „własnej wiedzy” autorów, fantazji i osobistych przeświadczeń, co w nowoczesny sposób określa kondycję romantycznego artysty i jego świadomość.

Krzysztof Trybuś (Zima romantyków. O pejzażach pamięci raz jeszcze) dokonuje w zasadzie rekapitulacji pewnych aspektów swoich wcześniejszych rozpoznań, zawartych w książce ${ }^{15}$. W zaprezentowanym tekście badacz pokazuje, jak istotnym motywem romantycznego zimowego obrazowania (u Mickiewicza, Coleridge’a, Müllera) jest pamięć. Odnosząc się do uwag Aleidy Assmann na temat przedstawiania trwałego i ciagłego charakteru pamięci poprzez metafory przestrzenne (s. 171), wskazuje jednocześnie na obecność, nakładanie się na nie w poezji romantycznej metafor czasowych, eksponujących nieciąłość i zapomnienie, co, jak trafnie zauważa, ujawnia odmienność romantycznej pamięci wobec jej wcześniejszego, oświeceniowego pojmowania jako osadzonej stale w określonym miejscu. Owa praca i niezakorzenienie przestrzenne pamięci — dopowiedzmy — znajduje kontynuację w literaturze późniejszej.

Tropem wyznaczonym przez Krzysztofa Trybusia podąża twórczo Magdalena Bąk-Wołoszyn (Romantyczne metafory pamięci — „ogród rozwidlajacych sie ścię̇kach” WWordsworth $i$ Mickiewicz7), prezentując, jak istotnym elementem konstytutywnym procesu kreacji poetyckiej Wordswortha i Mickiewicza były pamięć i wspominanie. Badaczka skupia uwagę na dziele Wordswortha The Prelude, wskazując, że poeta jezior stworzył w nim metajęzyk opisu swoich reminiscencji, miejsc, znamion czasu (spots of time), postrzegal zaś pamięć bardziej jako władze umysłu, a nie emocji, zależną od woli pamiętającego, dynamiczną co badaczka odnajduje również w twórczości Mickiewicza. Dla romantyków literatura jest forma pamięci oraz eksponowania autobiograficznych przeżyć ,ja”, aczkolwiek warto zadać pytanie o status owej „autobiograficzności”, o jej autentyczność, o możliwość autentycznej ekspresji, co do której romantycy mieli przecież istotne obiekcje.

Tytuł artykułu Marii Cieśli-Korytowskiej (Matka Boska od Pamięci. O cnocie roztropności w „Panu Tadeuszu”) zdaje się daleko odbiegać od tematyki całego tomu, jednak stanowi precyzyjną analizę związków między pamięcią i wyobraźnią oraz tego, w jak wielkim stopniu pamięć jest tematem Pana Tadeusza. Badaczka proponuje przeczytać poemat w sposób nieoczywisty, jako zbiór „miejsc” i „wyobrażeń”, którym, jak dowodzi, przypisać można określone znaczenia związane z kwestiami pamięci i wspominania. Wskazuje, że zarówno wyglądy, przedmioty, jak i miejsca pełnią w świecie utworu funkcję mnemoniczną. Cieśla-Korytowska wiąże ten zastosowany przez Mickiewicza zabieg z mnemonicznymi koncepcjami św. Tomasz z Akwinu i Cycerona. Pan Tadeusz jawi się jako „poemat pamięci”, ale memoria nie tyle ma przynieść ukojenie, co stać się środkiem do osiągnięcia cnoty — harmonii i zgody (s. 217).

15 K. Trybuś, Pamiéć romantyzmu. Studia nie tylko zpprzesžtości, Poznań 2011. 
W kolejnym studium, poświęconym literaturze romantycznej, Magdalena Siwiec (Lieu de memoire — lieu de folie. O „Królu zamcazyska” Seweryna Goszcayńskiego) proponuje lekturę utworu Goszczyńskiego jako szczególnego zapisu pamięci kulturowej, ponadepokowej i ponadjednostkowej, opartej na ciagłości pokoleniowej (s. 222), wskazując na decydujące znaczenie dla zrozumienia dzieła przeciwstawienia pamięci i historii. Badaczka, wykorzystując koncepcję „miejsc pamięci” Pierre’a Nory, wskazuje na ich produktywność w próbie zrozumienia zamysłu Goszczyńskiego w kontekście budowania postaci bohatera dzieła, Machnickiego, ale też samego utworu, bowiem — jak przekonująco dowodzi Siwiec - Król zamcåyska jest powieścią problematyzująca mechanizmy memoratywne.

Agata Seweryn (Upamiętniane, rekonstruowane, transponowane. Na marginesie Norwidowych ekfraz) ukazuje Norwida jako poetę kulturowej pamięci, który wielokrotnie odnosił się w swoich dziełach do innych tekstów kultury, na różne sposoby je transformując i rekontekstualizując. Badaczka proponuje nieoczywistą, ale przekonująca i produktywna poznawczo perspektywę: chce Norwidowe ekfrazy czytać jako świadectwa tego, jak poeta upamiętnia nimi, swoistymi hipertekstami, dzieła sztuki. Agata Seweryn dowodzi, że Norwid nie tyle traktuje sztukę jako pretekst do snucia rozważań na różne tematy, nie aktualizuje ich ani nie interpretuje, lecz konsekwentnie teatralizuje.

Trzy kolejne artykuły części „romantycznej” omawianego tomu (Elżbiety Koziołkiewicz Gdzie siega pamię́: kobieca, meska i autorska. „Perswazje” Jane Austen i „Cranford” Elizabeth Gaskell; Aliny Borkowskiej-Rychlewskiej „Odległość uświęca piękno”. Eugeniusza Delacroix uwagi o pamięci oraz Franciszka Ziejki Artur Grottger dtutem ržeźbiarzy upamiętniony) to świetnie zapisane szkice, które jednak nic istotnego do kwestii pamięci jako źródła dzieła sztuki nie wnoszą, traktując ją zaledwie hasłowo, czy nawet wyłącznie pretekstowo. Elżbieta Koziołkiewicz opisuje intertekstualne związki dwu brytyjskich powieści dziewiętnastowiecznych. Choć autorka zapowiada we wstępie otwarcie interesującej perspektywy: zbadania płciowych uwarunkowań stosunku do przeszłości (s. 252), to w istocie ogranicza się do bardziej tradycyjnej perspektywy oglądu dzieł. Alina Borkowska-Rychlewska starannie rekonstruuje sposób myślenia Delacroix na temat pamięci, zapisany w jego Diqiennikach, myśli te jednak są ledwie emblematyczne dla jego formacji i pokolenia. Franciszek Ziejka z kolei rozsnuwa zajmująca, pełną ciekawych szczegółów opowieść biograficzną o Grottgerze oraz opisuje różne sposoby upamiętnienia jego postaci po śmierci artysty.

Nie do końca trafna była też decyzja redaktorów o umieszczeniu w tomie poświęconym Mnemosyne socjologizującego studium Ewy Skorupy Wymasywanie pamięci a obowiazek pamieci, prezentującego polskie zmagania o zachowanie pamięci społecznej polskiej mniejszości w dzielnicy pruskiej w XIX wieku oraz, z drugiej strony, starań Niemców o rugowanie pamięci o polskich dziejach i tradycjach. Ten skądinąd zajmujący, faktograficznie ciekawy tekst, lokuje się zdecydowanie obok rozważań o roli pamięci w powstawaniu dzieła sztuki.

Wspomniany tekst Ewy Skorupy przypomina w przedostatniej swej części o roli pieśni polskiej w podtrzymywaniu narodowego ducha. Temu zagadnieniu — pieśni jako nośnika pamięci — poświęcony jest kolejny artykuł, Małgorzaty Sokalskiej („,Skaqd, jakimi drogi, na skeraydlach jakiej miłości i pamięci?” — pieśn jako nośnik pamięci w literaturze XIX i poczatteów XX wieku). Ponieważ autorka odżegnuje się od próby zdefiniowania pojęcia pieśni na potrzeby swojej pracy (s. 321), prezentuje zatem wybrane, zdecydowanie niejednorodne przykłady obecności różnych pieśni (i ludowych, i historyczno-patriotycznych, i stanowiących 
integralną część dzieła, bowiem powstałych w jego obrębie) w literaturze niemieckiej (Wilhelm Meister Goethego) oraz polskiej (Konrad Wallenrod Mickiewicza, Kunigas Kraszewskiego, Nad Niemnem Orzeszkowej i - co zaskakujące w kontekście zakresu czasowego zarysowanego w tytule szkicu — Noce $i$ dnie Dąbrowskiej). Tekst ten jest w istocie opisem kilku interesujących przypadków, autorka bada motyw pieśni obecny w dziełach literackich na wybranych, głównie XIX-wiecznych przykładach.

W kręgu tematyki XIX-wiecznej mieści się też — i domyka ów krąg zagadnień — szkic Andrzeja Waśki („Sześćdziesiat lat temu”. Pamięć i dystans epicki w powieści historycznej), Tytuł artykułu zapowiada szeroka perspektywę, poświęcony jest jednak powieściom historycznym Waltera Scotta (Waverley), Henryka Rzewuskiego (Pamiatki Soplicy) oraz Margaret Mitchell (Przemineto z wiatrem) - tym zatem, u których genezy legł „bezpośredni przekaz ustny o wydarzeniach z historii niedawnej, pozostającej w zasięgu społecznej pamięci komunikatywnej, zapamiętanych przez ogół” (s. 342). Waśko wskazuje liczne podobieństwa i analogie łączące tak odległe sobie kulturowo dzieła, przede wszystkim: oparcie opowieści na relacjach pokoleń skrajnych — dziadków i wnuków bądź prawnuków), korzystanie z ustnej tradycji rodzinnej i środowiskowej, odwoływanie się do pamięci cudzej, uczestników i świadków przeszłości, co wpływa na formę narracji powieściowej, sięganie po dramatyczne wydarzenia historii najnowszej, trzypokoleniowy dystans między czasem akcji a czasem powstania utworów, polemiczny wobec oficjalnego obraz przeszłości. Badacz dostrzega pokrewieństwo miedzy historycznym podaniem ustnym a literatura, dopowiedzmy więc: między pamięcią a dziełem.

Kolejna, czwartą część analizowanego tomu określić by można mianem intermedialnej. Składają się na nią cztery eseje.

Joanna Wojnicka (Pańska Polska cæy bratni Naród? Fatszowanie pamieci bistorycznej jako narzedzie propagandy na prayktadzie ,tematyki polskiej” w sowieckim kinie fabularnym) ciekawie faktograficznie pokazuje propagandowy wymiar radzieckiej kinematografii, choć czyni to dość powierzchownie, bo nie konfrontując głębiej swoich uwag o „temacie polskim” w sowieckim kinie ze zmieniającymi się realiami politycznymi.

Monika Schmitz-Emans (Fotografia i pamiéć w dziełach Wilhelma Genazino, W. G. Sebalda $i$ Gerharda Rotha) w niezwykle uporządkowanym, choć dość zdawkowym wywodzie analizuje związki fotografii i memorii jako tematu literackiego, wskazując na głębokie relacje między nimi i istotny wpływ fotografii na kompozycję omawianych dzieł literackich.

Olga Płaszczewska z kolei przypomina - co wręcz konieczne i oczywiste w omawianym zbiorze - postać włoskiego komparatysty, Mario Paza, skupiając się na przedstawieniu polskiemu czytelnikowi jego autobiograficznej, heterodoksyjnej (bo łączącej narrację wspomnieniową z esejem, traktatem, wypowiedziami krytyka sztuki i parabola) opowieści La casa della vita, która okazuje się być manifestem nierozdzielności literatury, sztuki i życia.

Różnym formom recepcji muzyki — wobec powstania i rozwoju przemysłu fonograficznego - poświęciła swój szkic Iwona Puchalska (Fonografia jako źródło muzycznej (nie) pamięci). Autorka omawia dwie zdawałoby się krańcowo odległe strategie odbioru muzyki - Johna Cage'a i Adama Zagajewskiego, wskazując na wspólne punkty ich refleksji dotyczące reprodukcyjnego, kreacyjnego i absolutyzującego wymiarów pamięci związanej z fonograficznym utrwalaniem muzyki. 
Piątą część książki stanowią teksty poświęcone polskiej i obcej literaturze współczesnej. Pomieszczone w niej artykuły prezentują — w różnym ujęciu — funkcję pamięci, indywidualnej i zbiorowej, w budowaniu wypowiedzi literackiej.

W świetnie skomponowanym eseju interpretacyjnym Anna Czabanowska-Wróbel („Oddajcie mi moje dzieciństwo...”. Pamięć i zapomnienie w twórczości Adama Zagajewskiego) idzie co prawda tropem rozpoznanym już wcześniej w pisarstwie autora Plótna, w istotny sposób jednak go dopełnia, wskazując na przenikanie się w tym dziele dwu sfer i typów doświadczenia: wspólnotowego i osobistego. Ta podwójna perspektywa wydaje się kluczowa dola zrozumienia istoty eseistyki i poezji Zagajewskiego.

Kwiryna Ziemba (Paweł Huelle: pamiéć jako zadanie i pržeznaczenie) generalnie podobna postawę dostrzega w twórczości Pawła Huellego, dla którego dzieł kwestia pamięci wydaje się kluczowa. Badaczka akcentuje postpamięciowy charakter jego wspominania, Huelle opisuje bowiem konsekwentnie mechanizmy pamięci dziedziczącej wspomnienia nieżyjących już bliskich, co więcej: poprzez, nazwijmy to tak, pamięciową empatię. I dzięki pamięci ciepła ludzkich relacji możliwe jest przełamanie międzyludzkiej obcości (s. 448) — co stanowi przecież, jak dowodzi Ziemba, jedno z głównych zadań pamięciowego projektu Huellego.

Tytuł tekstu Macieja Urbanowskiego (Pamięć komunižmu w najnowszej literaturže polskiej) jest obietnica na wyrost, ponieważ autor skupia się jedynie na trzech twórcach: Przemysławie Dakowiczu, Janie Polkowskim i Januszu Krasińskim. Badacz starannie i precyzyjnie omawia wybrane dzieła tych autorów: tom wierszy Głosy i powieść Ślady krwi Polkowskiego, Obcowanie. Manifesty i eseje, Afazje polska, Teorie wiersza polskiego, Przeklete continuum. Notatnik. smolenski i Łaczkę Dakowicza oraz, w dużym skrócie, tetralogię powieściową Krasińskiego Na stracenie, Twarza do ściany, Niemoc i Przed agoniq. Studium Urbanowskiego analizuje wspólne tym twórcom postulaty pamiętania i odpominania, rugowania kłamstwa — postulaty traktowane, zarówno przez pisarzy, jak i najwyraźniej przez autora szkicu, jako powinność twórcy oraz fundament tożsamości jednostkowej i zbiorowej. Pamięć (w tym opisywana pamięć o komunizmie) nie ma tu w istocie charakteru subiektywnego, nieuzgadnialnego z inną pamięcią, partykularnego. Ma natomiast służyć budowaniu narodowej wspólnoty jednolitych wartości. Z tego powodu brak jakiejś wyrazistej kompozycyjnej i myślowej przeciwwagi, stanowiska odmienne (np. Krzysztofa Vargi) sa ledwie zasygnalizowane.

Artykuł Anity Całek (Władza pamięci w „Ostatnim rozdaniu” Wiestawa Myśliwskiego i „Podróżach po skryptorium” Paula Austera) to przykład solidnej pracy komparatystycznej poświęconej dwu współczesnym powieściom, których — głównym tematem jest pamięć indywidualna, czego przekonująco w swoich analizach dowodzi autorka. Badaczka opisuje, jak Myśliwski i Auster pożytkują własne wspomnienia i doświadczenia na rzecz kreacji głównych bohaterów, pozbawionych jednak, co znamienne i wspólne, mocnej tożsamości. Obrazowanie pamięć w obu utworach ma charakter przestrzenny, co Całek słusznie wywodzi z inspiracji księga X. Wyz̧nań św. Augustyna, okazujących się, po raz kolejny, ważną inspiracją w konceptualizowaniu pamięci w dziele sztuki.

Domykający tę część książki szkic Jakuba Czernika (Historia — pamięć - narracja — tożsamość. „Dzieci pótnocy” Salmana Rushdiego) omawia „archeologiczny” wymiar i funkcję pamięci, kluczowy dla twórczości Rushdiego. Samo tworzenie dzieła pisarskiego jest dla tego artysty jak zapamiętywanie, jak odzyskiwanie pamięci, zawsze jednak indywidualnej i subiektywnej, niedającej pełnego dostępu do rzeczywistości, co bliskie opisywanym wcześniej poglądom i praktykom romantyków oraz całej nowoczesności. 
Swoistym smakowitym apendyksem do publikacji Mnemosyne. Pamię́ jako źródto dzieła squtuki są dwa teksty końcowe.

Marta Skwara we wstępie swojego eseju (Czy istnieje pamię́ o literaturže polskiej w literaturze swiatowej?) stawia kwestię, na ile literatura rodzima tworzy światowa. Jej rozwikłaniu służy kilka wyrazistych przykładów bardziej lub mniej czytelnych związków intertekstualnych dzieł obcych i polskich. Artykuł jest jednak przede wszystkim sygnałem braku refleksji nad wymiarem intertekstualności w polskich badaniach, a także nad recepcją naszej literatury oraz postulatem podjęcia takowych badań.

Problemy translatologiczne w kontekście pamięci tłumacza, działania mechanizmów wyobrażeniowych połączonych z mechanizmami pamięci, rozważa Elżbieta Tabakowska (Tłumacz, we władzy Mnemosyne). Konkretne przykłady dowodzą istotnej roli znajomości realiów kulturowych, pamięci struktur gramatycznych oraz ikoniczności.

Mnemosyne. Pamię́ jako źródło dzieła sz̧tuki to obszerny zbiór w większości niezwykle ciekawych i inspirujących studiów z zakresu obecności i funkcjonowania pamięci w sztuce. Tom jednocześnie nazbyt chyba różnorodny, kłopotliwie polimorficzny i za bardzo w rozmaitości sposobów ujmowania tytułowego zagadnienia rozległy, by nie powiedzieć: swobodny, co jednak zrozumiałe skoro zrodził się w efekcie interdyscyplinarnej konferencji. Warto na koniec podkreślić staranną szatę graficzną książki, aczkolwiek konsekwentne zapisywanie wszystkich cytatów (ale też tytułów utworów) kursywą, dalekie od zwyczajów przyjętych w tego typu publikacjach, wymaga wzmożonej czytelniczej uwagi.

TOMASZ CieŚLAK 